\title{
Pelatihan Pembuatan Media Pembelajaran Daring Bagi Guru SMA Menggunakan Open Broadcaster Software
}

\author{
Sunardi Sunardi*, Achmad Dito, January Audrey, \\ Rachmad Very Ananda Saputra, Syifa Riski Ardiningtias \\ *Universitas Ahmad Dahlan \\ *email: sunardi@mti.uad.ac.id
}

\begin{abstract}
This community service program carries out training on optimizing the use of Open Broadcaster Software (OBS) in online learning, primarily due to the Covid-19 pandemic. The training is given to 16 participants of SMAIT Abu Bakar Yogyakarta teachers. This training aims to introduce supporting media that can be used in the online teaching and learning process more interactively and present it live streaming via YouTube. In the pre-test, 69\% of participants had never been familiar with the term OBS. Only 19\% have observed people using OBS; in fact, none $(0 \%)$ have ever used OBS. After the training, participants gained additional knowledge/insight about OBS, and $94 \%$ agreed that the training that had been provided made learning more structured about OBS. Participants stated that $100 \%$ agreed that OBS could be further optimized for learning. The enthusiasm of the participants can be seen from after the training. $100 \%$ of the participants will participate again if this kind of training is held.
\end{abstract}

Keywords: Open Broadcaster Software; Online, Covid-19; Teaching and Learning Activities.

\section{Untuk Disitasi}

Sunardi, S., Dito, A., Audrey, J., Saputra, R. V. A., \& Ardiningtias, S. R. (2021). Pelatihan pembuatan media pembelajaran daring bagi guru SMA menggunakan open broadcaster software. Jurnal Nasional Pengabdian Masyarakat, 2(1), 28-38.

\section{Pendahuluan}

Seiring dengan perkembangan era globalisasi, dunia teknologi informasi dan komunikasi (TIK) juga berkembang dengan pesat. Pada abad 21 ini TIK sudah menjadi kebutuhan primer bagi banyak kalangan. Anshori (2017) menyampaikan bahwa konsep dan mekanisme belajar berbasis teknologi informasi (TI) mau tidak mau tak dapat dihindarkan. Adanya TIK berdampak positif dalam banyak pekerjaan yang dapat dilakukan secara lebih cepat, mudah, murah, dan efisien. Selain itu juga membuat informasi semakin terbuka dan tersebar luas dari dan ke seluruh dunia menembus batas ruang dan waktu (Jamun, 2018).

Penguasaan terhadap perangkat TIK perlu diajarkan pada semua tingkatan, diantaranya adalah guru. Salah satu indikator guru profesional dan kompeten adalah guru yang mampu beradaptasi dengan keilmuan yang semakin canggih dengan penguasaan TIK (Mugara, 2011). Pada masa pandemi Covid-19 seperti sekarang ini, semua kalangan terdampak tidak terkecuali guru atau tenaga pendidik dalam melaksanakan kegiatan belajar mengajar (KBM). Menurut Mansyur (2020), realitas menunjukkan bahwa dinamika pembelajaran di Indonesia saat ini terganggu oleh wabah Covid-19. 
KBM harus terus berjalan agar para siswa tidak ketinggalan pelajaran walaupun KBM secara tatap muka atau offline tidak memungkinkan untuk dijalankan dalam rangka menghindari laju penambahan kasus positif Covid-19. Menurut Marbun (2020), pemerintah telah menetapkan kebijakan bahwa semua masyarakat stay at home, termasuk kegiatan belajar, bekerja, dan beribadah. Oleh karena itu perlu dilakukan upaya agar KBM dapat terus berlangsung. Meskipun peserta didik berada di rumah, guru harus memastikan KBM tetap terus berjalan (Atsani, 2020).

Salah satu alternatif KBM yang bisa dilakukan adalah dengan cara pembelajaran online atau daring (dalam jaringan) menggunakan aplikasi atau software pendukung. Menurut Rachmawati, dkk (2020), penyampaian pendidikan dalam kegiatan formal maupun informal dialihkan pada metode online atau dalam jaringan secara radikal dan masif. Dengan demikian guru dan siswa harus melakukan KBM secara online atau tidak tatap muka di kelas seperti biasanya (Pujiasih, 2020). Terdapat banyak aplikasi atau software pendukung yang dapat digunakan dalam KBM daring. Demikian juga banyak media yang dapat digunakan untuk penyampaian materi dalam bentuk audio dan video.

Penggunaan audio dan video dalam KBM dapat dilakukan menggunakan mode asynchronous maupun synchronous. Mode asynchronous secara sederhana dipahami menggunakan media rekaman sehingga pengajar dan peserta didik tidak harus online dalam waktu bersamaan sehingga bahan ajar yang didistribusikan oleh guru dapat diakses oleh siswa kapanpun dan dimanapun siswa berada (Sadikin \& Hamidah, 2020). Asynchronous juga merupakan proses pembelajaran yang berlangsung secara tidak langsung antara peserta didik dengan sumber belajarnya, peserta didik dapat melakukan aktivitas belajar setiap saat tanpa harus menunggu kehadiran sumber belajar secara langsung (Wahyuningsih \& Sungkono, 2017). Mode ini merupakan sarana yang lebih hemat biaya, meminimalisir kendala perangkat atau jaringan, dan tidak memberatkan secara waktu karena tidak harus online secara realtime dalam rentang waktu yang tertentu.

Pembelajaran dengan mode synchronous atau secara langsung (live) mensyaratkan pengajar dan peserta didik untuk online pada waktu bersamaan secara realtime sehingga memungkinkan pembelajaran langsung berpusat pada pengajar (Pakpahan \& Fitriani, 2020). Narayana (2016) menyatakan bahwa synchronous juga merupakan proses pembelajaran yang menjadikan adanya interaksi langsung antara peserta didik dan instruktur melalui komunitas pembelajaran online dalam waktu yang sudah ditentukan. Mode ini biasa diselenggarakan seperti halnya teleconference diantaranya menggunakan media Zoom, Google Meet, dan Webex. Mode ini memungkinkan adanya komunikasi yang lebih interaktif sehingga lebih efektif dalam KBM dibanding mode asynchronous, namun bagi sebagaian orang memberatkan dalam hal biaya dan waktu.

Berdasarkan uraian di atas maka program pengabdian masyarakat ini melaksanakan pelatihan optimalisasi penggunaan Open Broadcaster Software dalam pembelajaran daring. Pelatihan diberikan kepada para guru SMAIT Abu Bakar Yogyakarta yang telah meminta secara resmi melalui surat kepada institusi penulis untuk diselenggarakan pelatihan tersebut karena sangat diperlukan oleh para guru dalam peningkatan kualitas pembelajaran terutama selama pandemi Covid19. Tujuan yang ingin dicapai dari pelaksanaan pelatihan ini adalah mengenalkan kepada peserta pelatihan mengenai media pendukung yang dapat digunakan dalam proses KBM secara daring. Selain itu juga melaksanakan pendampingan dalam menggunakan media dan aplikasi atau software yang dapat digunakan dalam membantu untuk memperbaiki 
kualitas proses KBM secara daring. Manfaat yang diharapkan dari pelatihan ini adalah proses KBM dapat terus berjalan dengan lebih efetif meski tidak dapat tatap muka secara langsung, para siswa tetap semangat mengikuti KBM secara daring karena materi disajikan dengan menarik, dan materi pembelajaran dapat di-record sehingga dapat digunakan secara berulangulang. Harapan lebih lanjut adalah guru dapat membuat materi pembelajaran yang lebih menarik serta interaktif dan dapat menyajikannya secara live streaming melalui YouTube.

\section{Solusi Masalah}

Open Broadcaster Software (OBS) seperti pada Gambar 1 merupakan software perekam dan pendukung untuk live streaming. OBS adalah perangkat lunak gratis dan open source yang fungsi utamanya adalah mengelola berbagai sumber input yang tersedia (Basilaia dkk., 2020). Dengan kedua software tersebut diharapkan para guru dapat menyajikan materi pembelajaran yang menarik sehingga para siswa tetap semangat dalam proses KBM meski tidak tatap muka secara langsung.

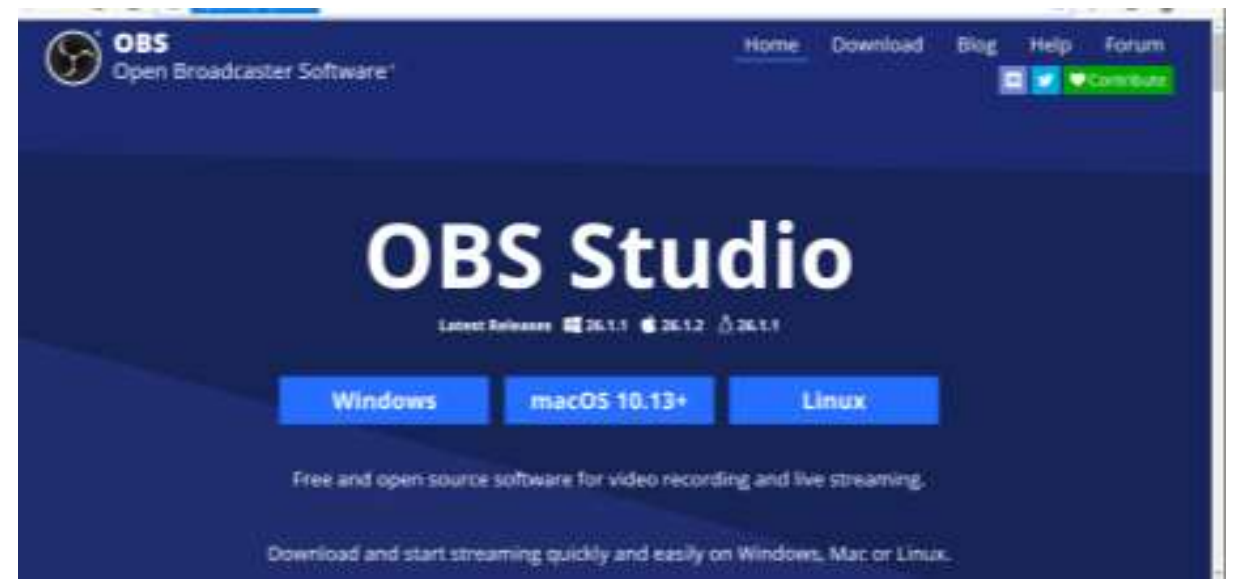

Gambar 1. OBS Studio

\section{Metode}

Dalam situasi pandemi Covid-19 seperti sekarang ini, KBM secara tatap muka tidak memungkinkan untuk dijalankan. KBM yang bisa dijalankan adalah dengan cara daring (dalam jaringan) atau online. Namun demikian tidak semua guru siap dan bisa menggunakan software pendukung untuk KBM secara daring tersebut. Guru awalnya seolah gagap dalam menggunakan software pendukung untuk pembelajaran daring karena dulunya belum pernah tahu atau mungkin tahu tetapi jarang menggunakan software tersebut. Namun sekarang situasinya berbeda, guru dituntut untuk bisa menggunakan software pendukung pembelajaran secara daring sehingga proses $\mathrm{KBM}$ dapat lebih menarik dan efektif dalam penyampaian materi oleh guru maupun pemahaman materi oleh siswa.

Pernah diadakan pelatihan Learning Management System (LMS) Moodle dari internal sekolah. Perlu dilakukan pelatihan dengan materi serupa untuk lebih terinternalisasi atau pelatihan dengan materi baru sehingga memiliki wawasan lebih luas dan bertambah semangat dalam pembelajaran daring. Gagasan yang diajukan untuk pemberdayaan masyarakat adalah mengadakan pelatihan dan pengenalan software pendukung untuk pembelajaran daring. Hal ini dilakukan agar para guru mendapatkan tambahan wawasan dan keterampilan baru dalam mempersiapkan pembelajaran daring yang lebih baik dan menarik.

Pihak-pihak yang dipertimbangkan untuk implementasi gagasan adalah para guru SMAIT 
Abu Bakar Yogyakarta sebanyak 16 orang. Langkah-langkah yang dilaksanaan dalam rangka implementasi pengabdian ini adalah membuat modul pelatihan, memberikan pelatihan secara offline dan disertai pendampingan, dan melakukan evaluasi terhadap materi maupun pelaksanaan pelatihan

OBS dapat merender video dengan cepat serta interface aplikasinya yang mudah dioperasikan. Teknik implementasi dilakukan melalui pelatihan yang disertai pendampingan membuat peserta interaktif dan lebih cepat memahami materi yang disampaikan.

Sebelum dilakukan pelatihan dilakukan pre-test dengan pertanyaan seperti pada Tabel 1.

Tabel 1. Daftar pertanyaan pre-test

\begin{tabular}{ll}
\hline Kode & Pertanyaan \\
\hline 1a & Saya pernah dengar istilah OBS \\
2a & Saya pernah mengamati orang menggunakan OBS \\
3a & Saya pernah menggunakan OBS secara mandiri \\
4a & Saya merasa OBS sebagai suatu media yang biasa \\
$5 \mathrm{a}$ & Saya merasa sudah cukup menguasai OBS \\
6a & Saya merasa tidak perlu ikut pelatihan OBS \\
\hline
\end{tabular}

Langkah pertama yang perlu dilakukan dalam pelatihan adalah mengunjungi website resmi OBS di https://obsproject.com/. Instalasi OBS disesuaikan dengan sistem operasi masingmasing maka otomatis OBS akan ter-download. Setelah selesai mengunduh file OBS, dilakukan instalasi pada software OBS studio. Selanjutnya melakukan set-up pada software OBS dan ikuti langkahnya sampai selesai melakukan instalasi OBS.
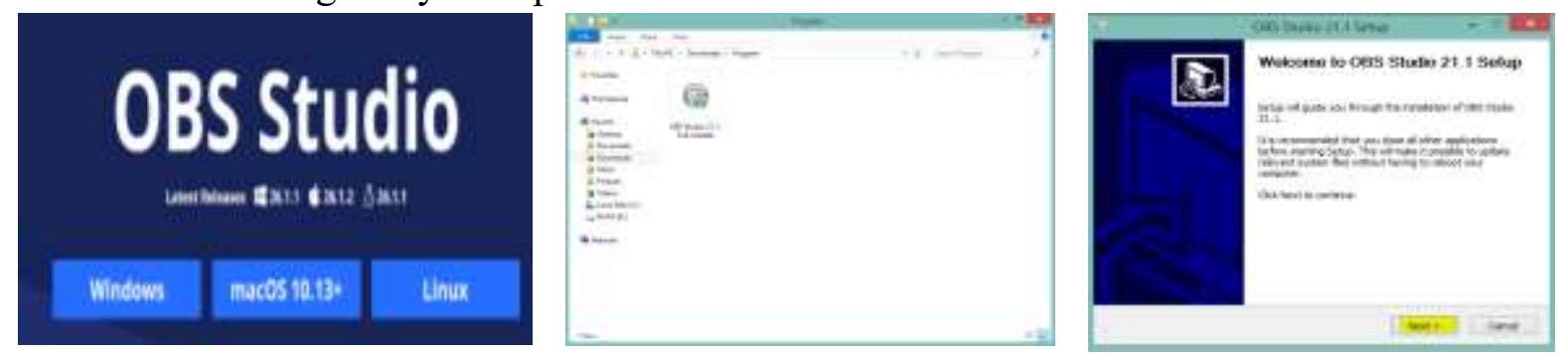

Gambar 2. Proses instalasi OBS
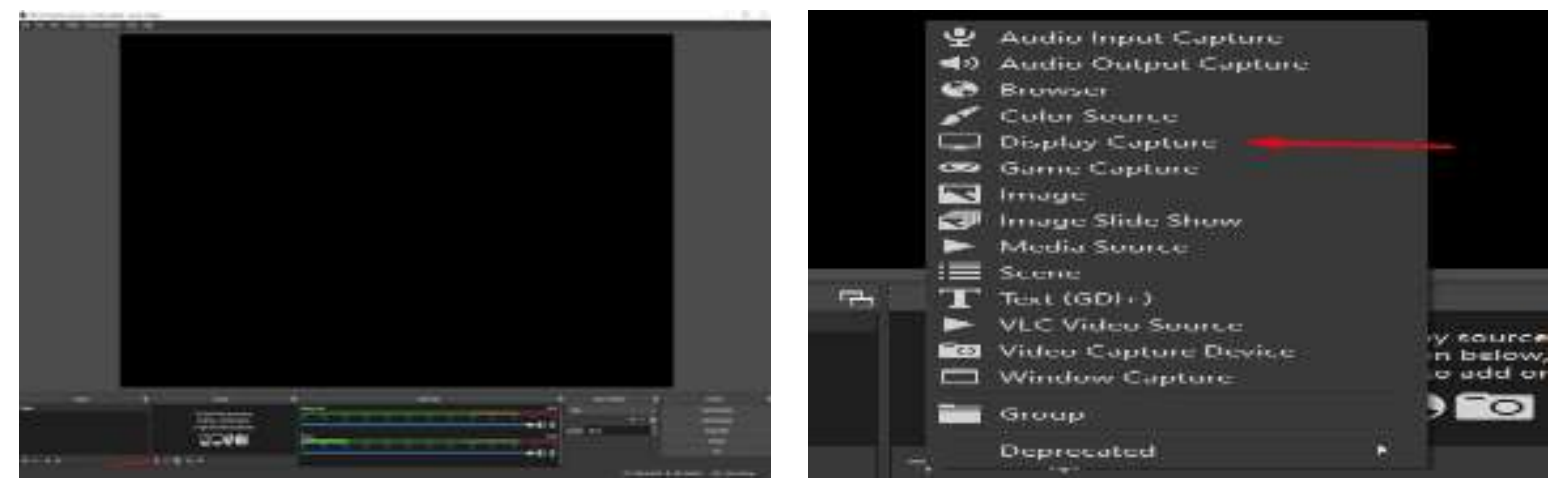

Gambar 3. Tampilan dan istilah 
Scene adalah tayangan yang akan ditampilkan di live streaming. Dalam satu scene dapat memiliki banyak Sources yang mengkombinasikan input video dari kamera, grafis, dan media. Untuk menambahkan scene klik "+” pada kolom Scenes. Kita dapat membuat scene sebanyak mungkin untuk memudahkan memilih konten yang akan ditampilkan.

Display capture berguna pada saat hendak merekam layar, berbagi layar sebagai media atau materi yang ingin disampaikan. Pada kolom source klik tanda + untuk menambahkan source display capture. Capture device berguna sebagai perekam wajah pada saat livestream atau pembuatan konten agar lebih menarik. Untuk menambahkan capture device ke dalam scene OBS, tekan + pada kolom source kemudian pilih capture device

Proses menambahkan text dapat dilakukan dengan cara pada kolom source tekan + kemudian pilih Text. Kemudian menginputkan kata yang ingin dimasukan dalam frame OBS. Proses menambahkan Gambar dapat dilakukan dengan cara pada kolom source klik tanda + kemudian pilih image. Kemudian pilih lokasi gambar pada komputer untuk ditampilkan di OBS.
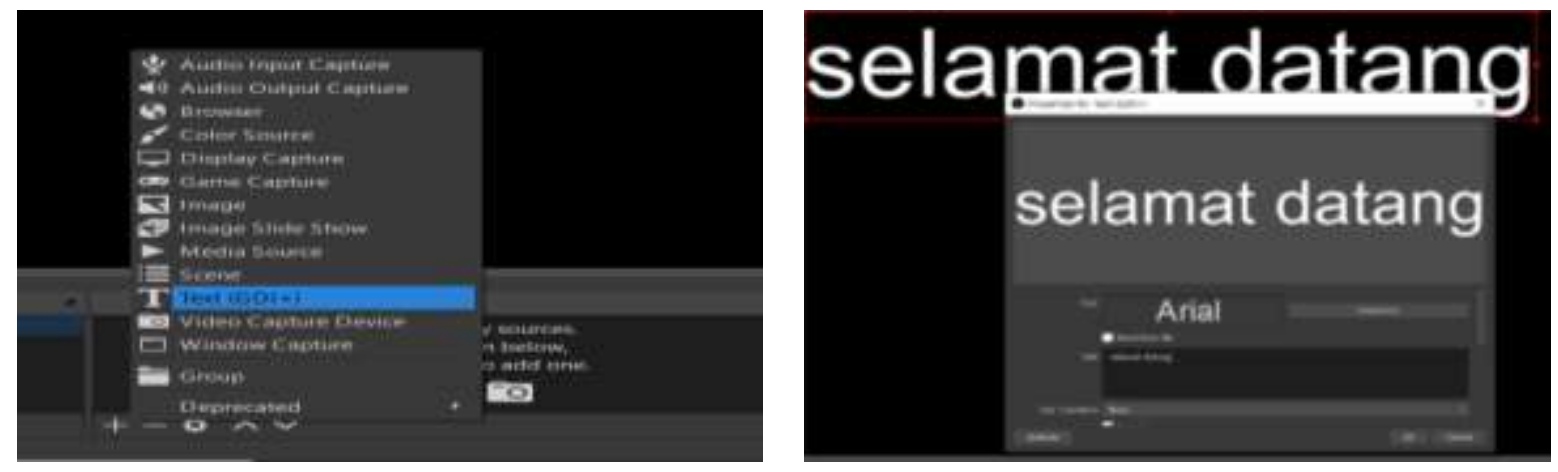

Gambar 4. Proses menambahkan teks
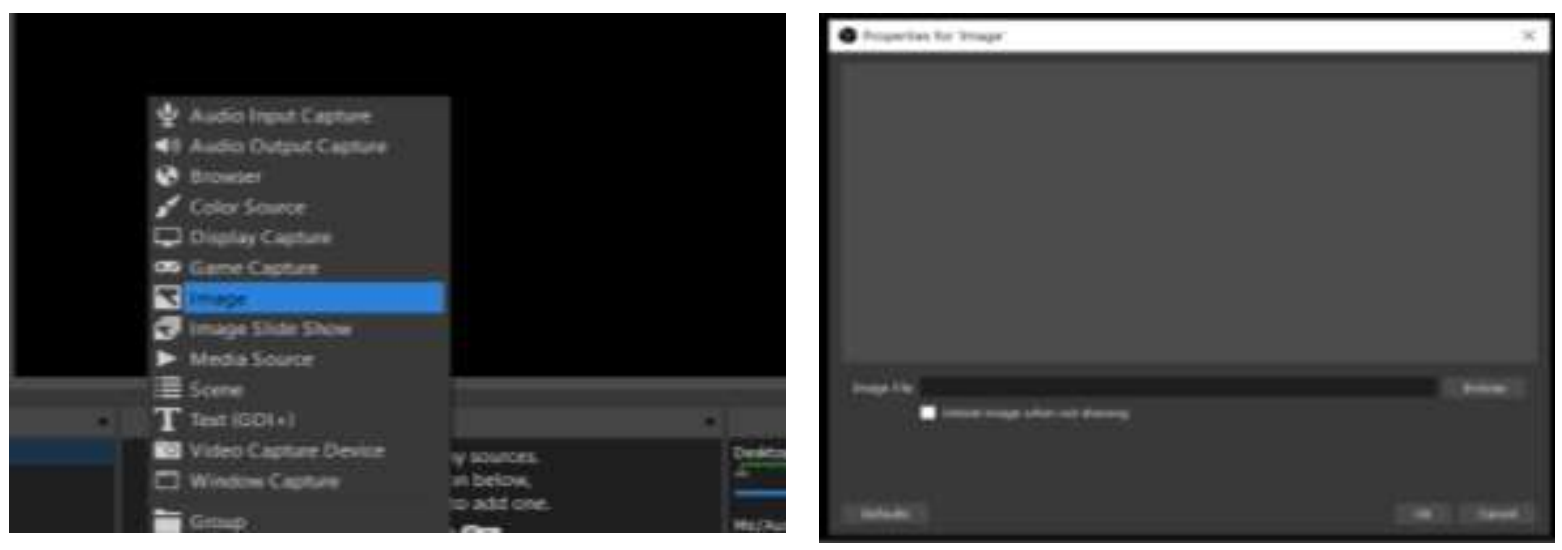

Gambar 5. Menambahkan gambar

Streaming via Youtube dapat dilakukan dengan cara kunjungi ke website www.youtube.com, Klik profile, kemudian masuk dengan menggunakan Channel atau akun youtube kemudian pilih menu "Buat" dan pilih opsi Live Streaming. Selanjutnya anda akan memilih opsi penjadwalan streaming anda, sesuai dengan keinginan penjadwalan anda untuk streaming. Selanjutnya karena memakai software OBS untuk menampilkan media pada saat streaming maka dianjurkan untuk memilih opsi "Software Untuk Streaming", kemudian akan 
mendapatkan keystream untuk melakukan streaming melalui OBS kemudian salin stream key ke OBS. Pilih menu Setting $>$ Stream $>$ kemudian salin keystream pada kolom keystream di OBS. Selanjutnya setelah selesai mengisi kolom stream key dengan benar, maka siap untuk melakukan streaming melalui youtube. Klik start streaming pada bar control untuk memulai streaming menggunakan OBS
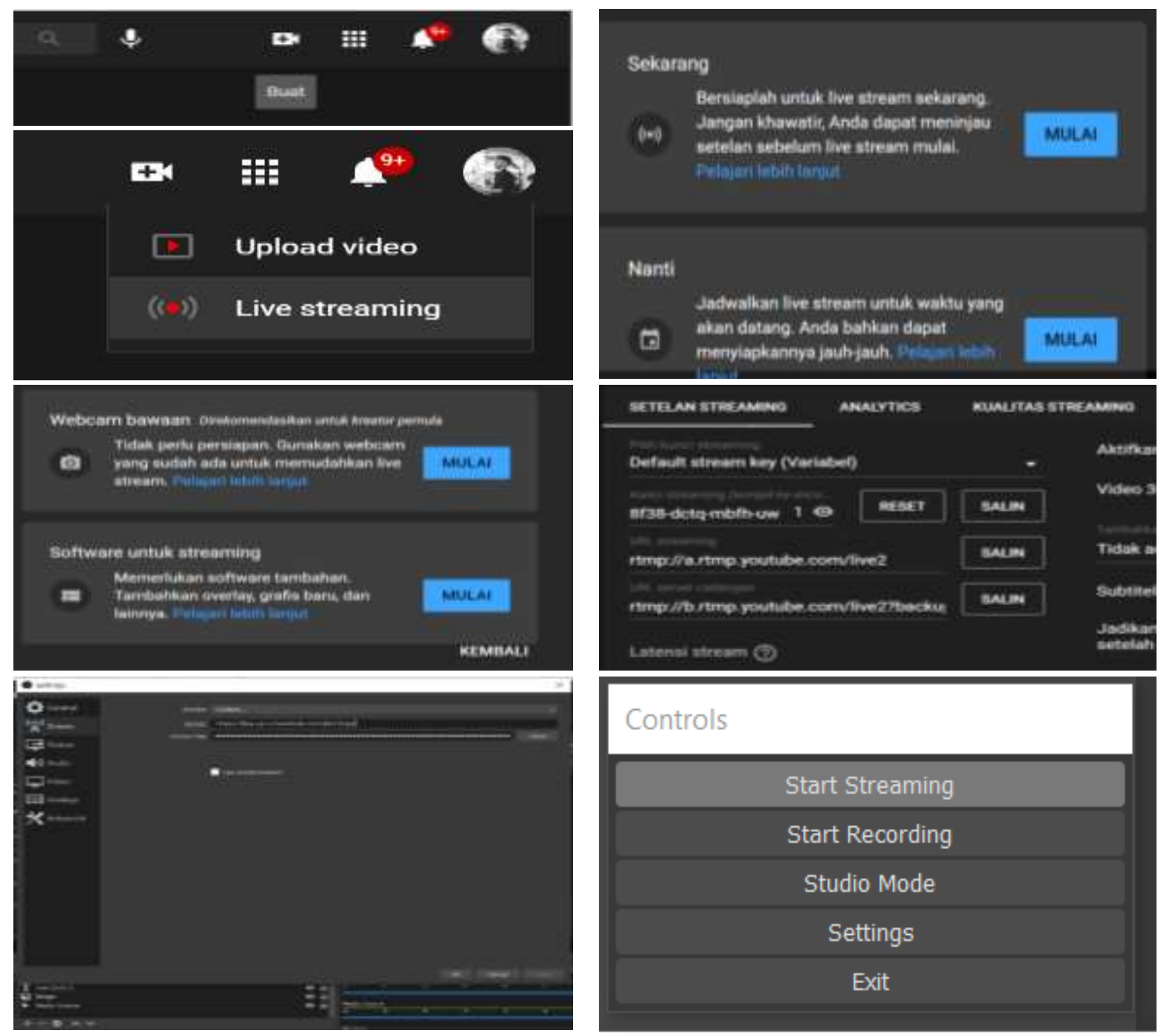

Gambar 6 Proses live streaming YouTube

Setelah dilakukan pelatihan dilakukan post-test dengan pertanyaan seperti pada Tabel 2.

Tabel 2. Daftar pertanyaan post-test

\begin{tabular}{ll}
\hline Kode & Pertanyaan \\
\hline $1 \mathrm{~b}$ & Pelatihan ini saya mendapatkan tambahan ilmu/wawasan tentang OBS \\
$\mathrm{2b}$ & Pelatihan ini membuat saya pernah mencoba menggunakan OBS \\
$\mathrm{3b}$ & Pelatihan ini membuat saya belajar lebih tersetruktur tentang OBS \\
$\mathrm{4b}$ & Pelatihan ini membuat saya merasa OBS bisa lebih dioptimalkan \\
$5 \mathrm{~b}$ & Pelatihan ini membuat kemampuan saya dalam OBS meningkat \\
$6 \mathrm{~b}$ & Pelatihan seperti ini jika diadakan lagi saya ingin kembali ikut \\
\hline
\end{tabular}

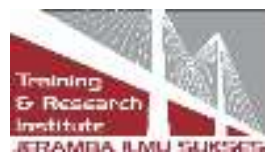




\section{Hasil dan Pembahasan}

Sebagian dokumentasi pelaksanaan kegiatan pelatihan OBS dapat dilihat pada Gambar 5.
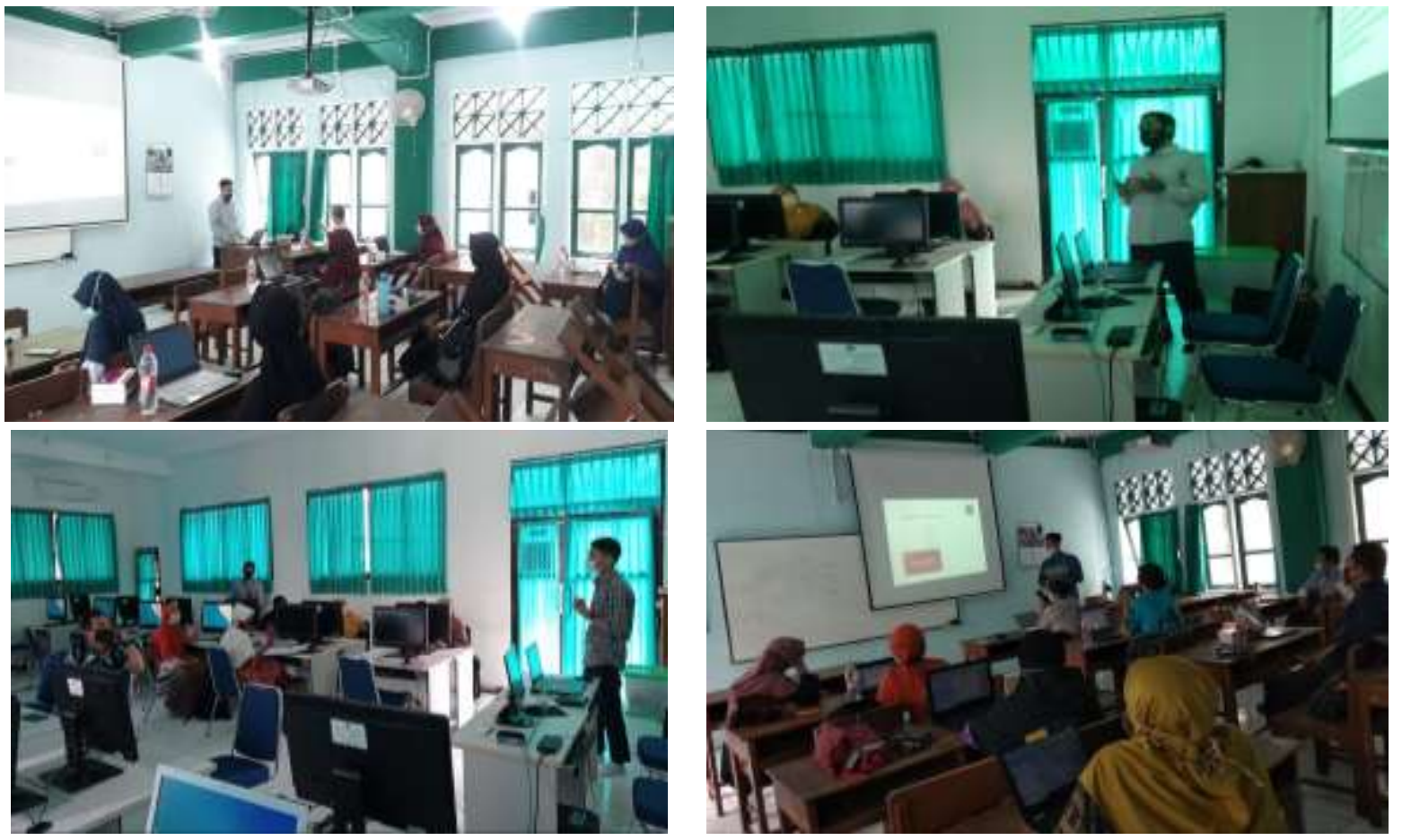

Gambar 7 Dokumentasi pelatihan OBS

Berdasarkan kuesioner yang diisi oleh total 16 peserta didapatkan hasil feedback seperti rekapitulasi pada Tabel 3 dengan disertai penjelasan secara grafis pada Gambar 8 sampai dengan Gambar 11.

Tabel 3. Rekapitulasi jawaban peserta (pre-test dan post-test)

\begin{tabular}{|c|c|c|c|c|c|c|c|}
\hline \multirow{2}{*}{ Pertanyaan } & \multicolumn{7}{|c|}{ Jawaban } \\
\cline { 2 - 8 } & SSS & SS & S & TS & STS & S,SS,SSS & TS,STS \\
\hline $1 \mathrm{a}$ & & & 5 & 8 & 3 & $31 \%$ & $69 \%$ \\
\hline $1 \mathrm{~b}$ & 3 & 9 & 4 & & & $100 \%$ & $0 \%$ \\
\hline $2 \mathrm{a}$ & & & 3 & 9 & 4 & $19 \%$ & $81 \%$ \\
\hline $2 \mathrm{~b}$ & & 9 & 7 & & & $100 \%$ & $0 \%$ \\
\hline $3 \mathrm{a}$ & & & & 10 & 6 & $0 \%$ & $100 \%$ \\
\hline $3 \mathrm{c}$ & 3 & 7 & 5 & 1 & & $94 \%$ & $6 \%$ \\
\hline $4 \mathrm{a}$ & & & 2 & 12 & 2 & $12 \%$ & $88 \%$ \\
\hline $4 \mathrm{~b}$ & 3 & 6 & 7 & & & $100 \%$ & $0 \%$ \\
\hline $5 \mathrm{a}$ & & & 3 & 9 & 4 & $19 \%$ & $81 \%$ \\
\hline $5 \mathrm{~b}$ & 2 & 5 & 9 & & & $100 \%$ & $0 \%$ \\
\hline $6 \mathrm{a}$ & & & 1 & 11 & 4 & $6 \%$ & $94 \%$ \\
\hline $6 \mathrm{c}$ & 2 & 7 & 7 & & & $100 \%$ & $0 \%$ \\
\hline
\end{tabular}


Pada Gambar 8, sebagai data pre-test, terdapat 69\% peserta belum pernah mengenal istilah OBS atau hanya $31 \%$ yang pernah mendengar istilah OBS. Jika dicermati lebih lanjut, hanya $19 \%$ pernah mengamati orang menggunakan OBS, bahkan tidak ada satupun $(0 \%)$ yang pernah menggunakan OBS sehingga kemampuan penggunaan OBS sebesar 0\%.

Saya pernah dengar istilah OBS

16 reaponses

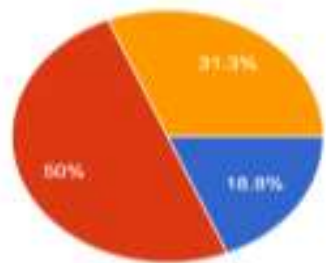

Saya pernah mengamati orang menggunakan OBS 16 responaes

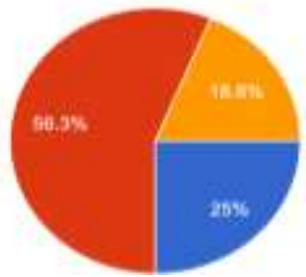

Saya pernah menggunakan OBS secara mandir 16 respanses

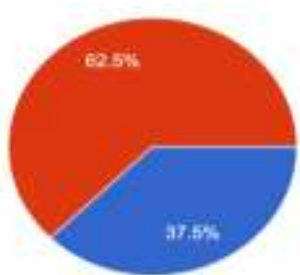

Saya merasa sudah cukup menguasai OBS 16 remonsent

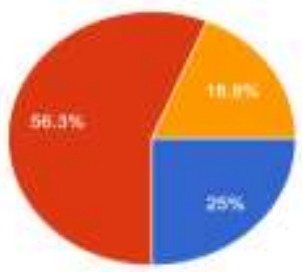

- Eangat Thak Eetuju

- ndah Setaigy

- Betiogu

Fanoai tetioi

- Sangat Setuiu 5ehal
Sangat Tidak Setuitu

- Trak Belied

- tietupa

- Sangat Setudu

- Somaat Betaju Bekai

Sanoar Tidak Solve

- Titak Setuju

Setulu

- Sancan Selujes

- Sangm Seluja Seker

Gambar 8. Pengetahuan dan pengalaman penggunaan OBS (pre-test)

Setelah pelatihan, seperti pada Gambar 9, terdapat 100\% menyetujui jika pelatihan ini mendapatkan tambahan ilmu/wawasan tentang OBS dan 100\% membuat pernah mencoba menggunakan OBS dengan 94\% setuju bahwa pelatihan yang telah diberikan membuat belajar lebih terstruktur tentang OBS.

Seperti pada Gambar 9, walaupun belum pernah menggunakan atau tidak menguasai namun 
meyakini bahwa OBS bukan sekedar media yang biasa sehingga $100 \%$ setelah pelatihan menyatakan kemampuan dalam penggunaan OBS meningkat. Hal ini terkonfirmasi setelah pelatihan menyatakan bahwa $100 \%$ menyetujui OBS bisa lebih dioptimalkan untuk pembelajaran.

Pelatihan ini saya mendapatican tambahan llmulwawasan tentang OBS

16 respanaet

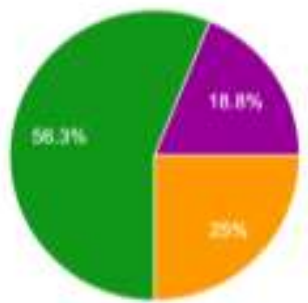

Pelatihan ini membuat saya pernah mencoba menggunakan OBS 16 responses

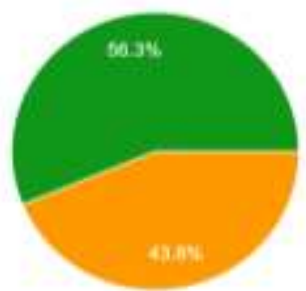

- Sangar Tacer Betuiu

Tidak Setuja

- Setuju

- Bangar Senpa

- Sanoat Seheu Sekai

Pelatihan ini membuat saya belajar lebih tersotruktur tentang OBS 16 respansen

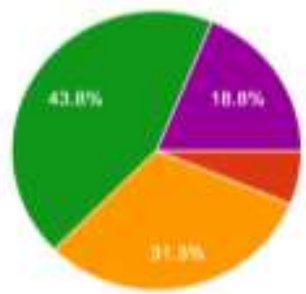

- Sangat Tisal Setequ

- Tidak Satuks

Sotujo

Bangat Slespe

- sangat flespu tesai

Gambar 9. Pengetahuan dan pengalaman penggunaan OBS (post-test)

Pelatihan ini membuat kemampuan saya dalam OBS meningkat

16 response:

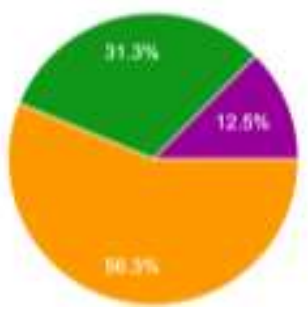

- Songat Titak Setudu

Trak Stetar

Stetup

- Sergat Setuju

- Smanat Setiju Iekat 
Pelatihan ini membuat saya merasa OBS bisa lebih dioptimalkan 16 rempanses

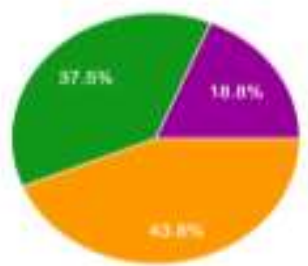

Sangat Tidak Sotuip - Tidak Beney

- Betula

- Sangat Sebiju

- Sangat Bethín sekai

Gambar 10. Kemampuan dan keyakinan OBS bisa dioptimalkan untuk pembelajaran (posttest)

Antusias atau semangat peserta cukup tinggi seperti dapat dilihat pada Gambar 11. Sebelum pelatihan terdapat $94 \%$ peserta menganggap perlu mengikuti pelatihan OBS dan setelah pelatihan $100 \%$ peserta akan ikut lagi jika diadakan pelatihan seperti ini.
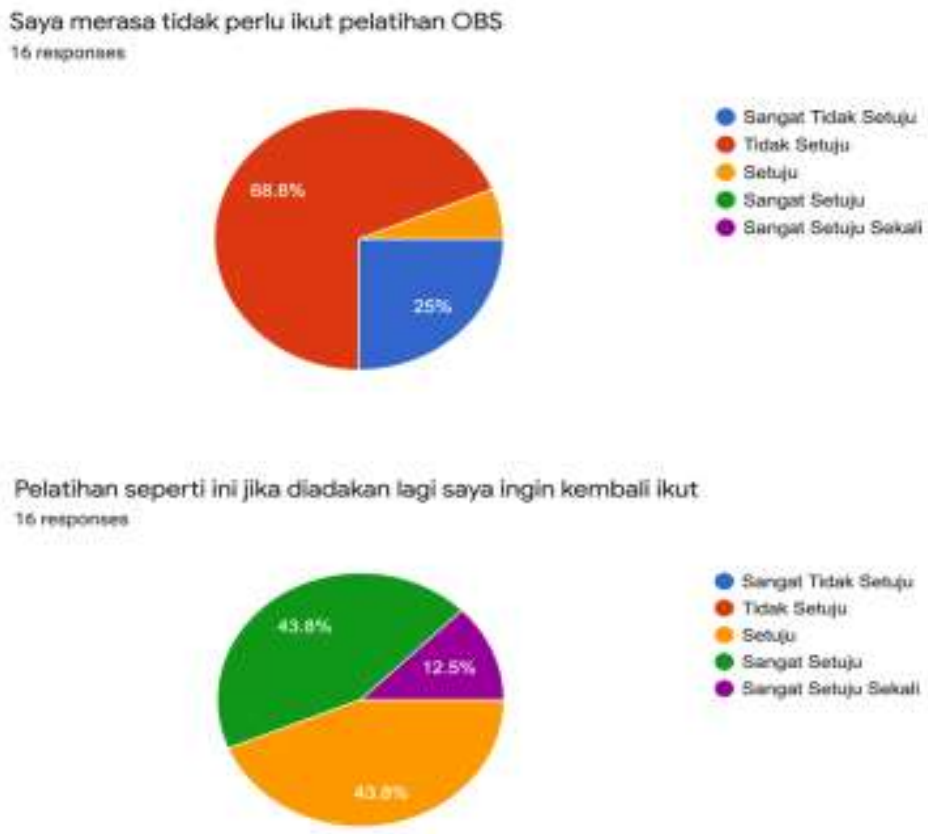

Gambar 11. Antusiasme pelatihan OBS (pre-test dan post-test)

\section{Kesimpulan}

Program pengabdian masyarakat ini telah berhasil menyelenggarakan pelatihan optimalisasi penggunaan Open Broadcaster Software (OBS) dalam pembelajaran daring kepada para peserta guru SMAIT Abu Bakar Yogyakarta. Pelatihan telah mengenalkan media pendukung yang dapat digunakan dalam proses kegiatan belajar mengajar secara daring secara lebih interaktif dan menyajikannya secara live streaming melalui YouTube. Setelah pelatihan peserta mendapatkan tambahan ilmu/wawasan tentang OBS dan pelatihan telah memberikan pembelajaran lebih terstruktur tentang OBS. Seluruh peserta menyatakan setujui bahwa OBS bisa lebih dioptimalkan untuk pembelajaran dan menyatakan sangat antusias untuk mengikuti lagi jika diadakan pelatihan lanjutan. 


\section{Daftar Pustaka}

Anshori, S. (2017). Pemanfaatan TIK sebagai sumber dan media pembelajaran di sekolah. Civic-Culture: Jurnal Ilmu Pendidikan PKn dan Sosial Budaya, 1(1), 10-20

Atsani, K. H. L. G. M. Z. (2020). Transformasi media pembelajaran pada masa pandemi covid-19. Al-Hikmah: Jurnal Studi Islam, 1(1), 82-93.

Basilaia, G., Dgebuadze, M., Kantaria, M., \& Chokhonelidze, G. (2020). Replacing the classic learning form at universities as an immediate response to the Covid-19 virus infection in Georgia. International Journal for Research in Applied Science and Engineering Technology (IJRASET), 8, 101-108.

Jamun, Y. M. (2018). Dampak teknologi terhadap pendidikan. Jurnal Pendidikan Dan Kebudayaan Missio, 10(1), 48-52.

Mansyur, A. R. (2020). Dampak covid-19 terhadap dinamika pembelajaran di indonesia. Education and Learning Journal, 1(2), 113-123.

Marbun, P. (2020). Disain pembelajaran online pada era dan pasca Covid-19. CSRID (Computer Science research and its development journal), 12(2), 129-142.

Mugara, R. (2011). Meningkatkan kompetensi guru melalui penguasaan teknologi informasi dan komunikasi (TIK). Prodi Pengembangan Kurikulum. Universitas Pendidikan Indonesia. Sunan Kalijaga: Yogyakarta.

Narayana, I. W. G. (2016). Analisis terhadap hasil penggunaan metode pembelajaran synchronous dan asynchronous. SemNasTeknoMedia Online, 4(1), 1-4.

Pakpahan, R., \& Fitriani, Y. (2020). Analisa pemanfaatan teknologi informasi dalam pembelajaran jarak jauh di tengah pandemi virus corona covid-19. Journal of Information System, Applied, Management, Accounting and Research, 4(2), 30-36.

Pujiasih, E. (2020). Membangun generasi emas dengan variasi pembelajaran online di masa pandemi covid-19. Ideguru: Jurnal Karya Ilmiah Guru, 5(1), 42-48.

Rachmawati, Y., Ma'arif, M., Fadhillah, N., Inayah, N., Ummah, K., Siregar, M. N. F., Amalyaningsih, R., Aftannailah, F., \& Auliyah, A. (2020). Studi eksplorasi studi eksplorasi pembelajaran pendidikan ipa saat masa pandemi Covid-19 di UIN Sunan Ampel Surabaya. Indonesian Journal of Science Learning, 1(1), 32-36.

Sadikin, A., \& Hamidah, A. (2020). Pembelajaran daring di tengah wabah Covid-19: (online learning in the middle of the Covid-19 pandemic). Biodik, 6(2), 214-224.

Wahyuningsih, D., \& Sungkono, S. (2017). Peningkatkan interaktivitas pembelajaran melalui penggunaan komunikasi asynchronous di Universitas Negeri Yogyakarta. Jurnal Inovasi Teknologi Pendidikan, 4(2), 227-237.

\section{Copyrights}

Copyright for this article is retained by the author(s), with first publication rights granted to the journal.

This is an open-access article distributed under the terms and conditions of the Creative Commons Attribution license (http://creativecommons.org/licenses/by/4.0/) 